\title{
ПАРАМЕНТСКИЕ ВЫБОРЫ В ИСПАНИИ: СОЦИАЛИСТЫ ВЕРНУЛИСЬ ВО ВЛАСТЬ, И ТЕПЕРЬ - НАДОЛГО
}

Аннотация. Автор анализирует итоги парламентских выборов в Испании (28.04.2019), победителем которых стала Испанская сочиалистическая рабочая партия (ИСРП), последовавший затем долгий период поиска союзников для создания левого правительства. Завоеванных ИСРП 123 депутатских мандатов в Конгрессе депутатов - нижней палате парламента оказалось недостаточно, чтобы в одиночку выиграть голосование (необходимо 176 голосов) в нём и привести своего лидера Педро Санчеса к власти. Естественным союзником была партия Подемос (41 депутат), от ультра-левизны которой в последние год-два мало что осталось. Но даже при успешных переговорах с её амбициозным лидером Пабло Иглесиасом и этого было бы мало. П. Санчес категорически отверг саму возможность блока с партией Сьюдаданос («Граждане»), подвергнувщей его в ходе предвыборной кампании оголтельм обвинениям в предательстве национальных интересов и потакании каталонским сепаратистам. В то же время он всячески избегал варианта переговоров с теми же левыми республиканцами Каталонии, активныли сторонниками независимости региона, чтобы не быть связанным никакими обещаниями на будущее. Пасьянс оставался открытым в отношении баскских националистов и мелких региональных депутатских групп, хотя и в этом случае не всё было однозначно. Итог известен: лидер сочиалистов прошел горнило парламента. Автор даёт прогноз развития ситуачии в Испании после самых непредсказуемых досрочных парламентских выборов, во многом изменивщих политический ландшафт страны.

Ключевые слова: досрочные парламентские выборы, ультрарадикалы из Vох, голосование в парламенте, новые политические лидеры, сочиально-экономические декреты, борьба за правый центр, кризис в «Подемос», перспективы формирования левого правительства.

Серьёзная фрагментация политического пространства страны, отразившаяся на работе практически всех государственных институтов, привела в итоге к тому, что Испания с 5 марта и до 28 апреля 2019 г. жила без правительства и без парламента. Политическая и экономическая жизнь практически замерла. Зато возросла активность и обещания партийных вождей, в случае прихода к управлению Испанией, навести, наконец, порядок в экономике и сохранить её единство в противостоянии с каталонскими сепаратистами. Уход со сцены недолгого правительства социалистов был прогнозируемым с того самого момента, когда лидеру соцпартии Педро Санчесу всего с 84 из 350 депутатов в парламенте удалось, благодаря неожиданной поддержке правой Сьюдаданос («Граждане»), националистических партий Каталонии и Страны басков, избавиться от правившей страной Народной партии и её лидера М. Рахоя. Но уже тогда было ясно, что это - пиррова победа.

Рубиконом, который не смог преодолеть П. Санчес, стало голосование в Конгрессе де-

\footnotetext{
(C) Верников Владимир Леонидович - старший научный сотрудник, руководитель Центра иберийских исследований Отдела страновых исследований ИЕ РАН. Адрес: 125009, Россия, Москва, ул. Моховая, д. 11, стр. 3. E-mail: vverkai@gmail.com.
}

DOI: http://dx.doi.org/10.15211/vestnikieran320193641 
путатов - нижней палате парламента по бюджету страны на 2019 г. Социалисты, предлагавшие в нём серьёзные и глубокие социально-экономические реформы, оказались почти в одиночестве, потеряв поддержку каталонских и баскской националистических партий, а Народная партия (НП) и Сьюдаданос повели исступленную медийную атаку на самого Санчеса и соцпартию. Их обвиняли в предательстве национальных интересов, в намерении разрушить единство страны потаканием планам каталонских сепаратистов и в бюджетном расточительстве в угоду своим идеологическим установкам. Подписанные премьером декреты, которые они уничижительно называли «decretasos» (по-испански это означает негативную коннотацию содержания), обещали в случае прихода к власти тут же отменить ${ }^{1}$. Итоги парламентских выборов оказались для них разочаровывающими, а обещания - пустым бахвальством.

Что же это за декреты, которые, несомненно, прибавили социалистам сторонников на выборах? Снижение возрастного ценза с 55 лет до 52-х для получения субсидии по безработице. Введение строгого учёта рабочего времени, чтобы избежать неоплачиваемых сверхурочных часов. Увеличение пособия бедным семьям с детьми до 12,313 евро в год. Повышение минимальной оплаты труда в сельском хозяйстве и снижение на 14,6\% выплат в фонд социального страхования во внесезонные периоды сельхозработ. Все декреты имеют социальную направленность, они фигурировали и в отвергнутом парламентом бюджете на 2019 г. Но на их имплементацию нужны немалые средства, источник которых не известен.

Обещанные после прихода к власти через месяц досрочные парламентские выборы умный и прагматичный Санчес оттянул на девять месяцев, пытаясь за время руководства правительством провести через парламент ряд социально ориентированных законов из арсенала соцпартии, но они были заблокированы правой оппозицией и обрели жизнь в виде декретов уже после роспуска парламента. Это произошло потому, что социалисты лишились поддержки каталонских националистов, потребовавших от правительства выполнения договорённостей, содержание которых до сих пор неизвестно. Речь, предполагают испанские политологи, идёт о проведении легального референдума о независимости Каталонии и амнистии лидеров событий 1 октября 2017 г. в Барселоне, находящихся сейчас под судом или под залогом на свободе за попытку антиконституционного мятежа. Если Верховный суд докажет их вину в организации антиконституционного восстания и растрате бюджетных средств, сроки тюремного заключения могут достичь 25 лет, что вызывает непрекращающиеся массовые протесты в Каталонии сторонников независимости. Они требуют проведения легального референдума об отделении от Испании.

На это правительство пойти не могло, не может и сейчас, хотя и пыталось договориться с каталонскими лидерами о ведении переговоров по конфликтным проблемам взаимоотношений и, безусловно, продолжит эту политику на новом этапе руководства страной. Что бы ни говорили лидеры НП и Сьюдаданос, но даже девять месяцев руководства страной П. Санчесом показали, что у социалистов есть профессиональная команда политических переговорщиков и экономических управленцев, что министры бывшего правительства не допустили ни одной серьёзной ошибки в определении курса страны в экономической и социальной сферах, а их идеологическая платформа оказалась созвучной ожиданиям большого сегмента испанского общества, разочаровавшегося в предыдущих правительствах правых. В переводе на язык цифр это и вылилось в победу социалистов на парламентских выборах без абсолютного большинства.

Теперь вопрос в том, каким будет правительство социалистов, с кем Санчесу придётся идти на мессу для получения вотума доверия в Конгрессе депутатов - ведь явных союзников

\footnotetext{
${ }^{1}$ El Pais, 19.02.2019.
} 
и партнёров для создания коалиции у них немного, разве что Подемос, которая претендует на участие в правительстве, но не находит понимания в руководстве Соцпартии. Причина - в идеологических разногласиях по многим проблемам экономической политики и весьма спорная позиция в поддержку законного референдума в Каталонии о независимости региона, что в корне противоречит политике социалистов. Санчес опасается, что вхождение представителей Подемос в правительство создаст в нём опасную конфликтность и неприятие общественным мнением, снизит эффективность работы ненужными процедурными проволочками.

Известно, что в испанской политической жизни бывают непредсказуемые телодвижения. Не исключена, вопреки всем заклинаниям Альберто Риверы до и даже после выборов о невозможности какого-либо союза с социалистами, поддержка «Гражданами» П. Санчеса при голосовании вотума доверия в парламенте новому главе кабинета. В сумме у них было бы 180 мандатов, что гарантирует стабильность кабинета и развязанные руки для проведения совместно выработанной платформы взаимодействия. Однако никто не гарантирует возможность и желание А. Риверы искать это взаимодействие. Вопрос о вхождении партии в правительство не стоит - она намерена оставаться в жёсткой оппозиции социалистам, чтобы перехватить у Народной партии роль лидера в правом спектре политической борьбы.

Сьюдаданос по числу депутатов стала третьей фракцией в парламенте, но метания А. Риверы с одного политического фланга на другой, его короткий флирт с социалистами, а затем двусмысленное заигрывание с НП, неконтролируемый инстинкт власти, к которой он стремится любой ценой, вызывают к нему глубокое недоверие не только политических лидеров, но и сторонников собственной партии, в которой всё громче слышны голоса о его неминуемой отставке. Произойдёт это вскоре после выборов, сказать трудно, но при всей своей напористости Сьюдаданос не обыграла НП на этих выборах, так что ситуативная поддержка социалистов при голосовании вотума доверия новому правительству не кажется такой уж нереальной.

Теоретически попутчиками могут стать и националистические партии Каталонии и Страны басков, неожиданно получившие значительное количество депутатских мандатов. Но П. Санчес вряд ли обратится к ним за поддержкой, не желая стать в будущем заложником их невыполнимых требований. Пока он категорически отрицает такой шаг, хотя по инсайдерской информации, просочившейся в СМИ, в соцпартии держат двери открытыми для любых пактов в случае формирования правительства меньшинства. Остаются в резерве небольшие региональные партии, но их представительство невелико и не может кардинально повлиять на результаты голосования в Конгрессе депутатов в пользу социалистов.

Жестокое поражение на выборах правых партий, и в первую очередь народников (они завоевали всего 66 депутатских мест, что является худшим результатом за всю историю существования партии), которым некоторые социологические опросы ещё в феврале отдавали даже абсолютное большинство в парламенте, в корне изменило политический ландшафт в Испании. Экономическая программа нового лидера НП Пабло Касадо, не нашедшая поддержки у избирателей, была направлена на «институциональное усиление» и включала принятие ряда законов по реформированию административно - управленческого аппарата, как, например, унификация компетенций в системе образования и здравоохранении, большее присутствие государства в автономных сообществах, усиление роли испанского языка в Каталонии, Стране басков, Валенсии, Наварре и на Балеарах. Политический посыл правому избирателю прозвучал, а экономический и социальный остались в секрете, что, считают испанские политологи, и привело к провалу.

НП, не оправившаяся от внутреннего раскола после скандальной отставки М. Рахоя и в

Научно-аналитический вестник ИЕ РАН, 2019, №3 
отсутствие харизматичного лидера, по сути,в одиночестве вошла в предвыборные баталии, конкурируя со Сьюдаданос за избирателя правого спектра политической мозаики. Договориться о едином блоке им не удалось. Поведение А. Риверы было непредсказуемо. Об общих списках кандидатов речь и вовсе не шла, а, напротив, его стратегия была направлена на «откусывание» у народников части электората с помощью привлечения в свои ряды политических перебежчиков из НП, которым были предложены первые номера в выборных бюллетенях вместо собственных региональных активистов, отодвинутых на второй план. Несколько таких случаев на региональных праймериз привели к скандалу и показали, что за правую политическую нишу между обеими партиями шла нешуточная борьба без правил, которая в итоге обернулась растаскиванием идеологически однородного избирателя по разным политическим квартирам ${ }^{1}$.

Это априори не сулило победы на выборах ни одной из них, что и случилось. Тем более что на том же поле появился новый игрок - праворадикальная Vox («Голос»), в которой много выходцев из обеих партий и даже из соцпартии и Подемос. Она успешно дебютировала на недавних региональных выборах в Андалусии (12 депутатских мандатов) и выдвинула на парламентских выборах своих кандидатов во всех регионах. Лидеры Vox также категорически отвергли вариант каких-либо пред- и поствыборных блоков со своими партнёрами по андалусийскому сценарию - НП и Сьюдаданос, и рассчитывали на успех в одиночку. Испанские обозреватели с самого начала не верили в успешный дебют партии на парламентских выборах, отмечая несовместимость абсолютного большинства её идеологических концепций с испанской конституцией и с либерально-демократическими традициями испанского социума.

Они объясняют её появление на политической сцене ростом националистических настроений как ответ на сепаратистские требования некоторых регионов, но рецепт борьбы за единство страны ультраправые видят в ликвидации автономного устройства и превращении её в унитарное государство. Прокламируя традиционные католические ценности при падении в обществе авторитета католической церкви, VOX выступает за запрет абортов и однополых браков, депортацию нелегальных исламских иммигрантов и против гендерного равенства, отдавая предпочтение мужской части населения. Но, как ни странно, эти и многие другие экстравагантные идеи находят понимание и поддержку электората, разочаровавшегося в политике традиционных партий, - 10,3\% голосов (2,7 млн сторонников) вынуждают обозревателей задуматься об этом феномене в XXI в.

В последние месяцы её лидеры даже снизили порог своих радикальных лозунгов в публичных выступлениях. Однако, повторимся, партия искала поддержку во всё том же правом спектре электората, что НП и Сьюдаданос, объективно снижая потенциал каждой из них. Vox всё же удалось получить 24 мандата и впервые после выборов 1979 г. войти в парламент как выразителю праворадикальных взглядов, о которых, казалось, в стране давно уже забыли. Сама Vox категорически не согласна с определением праворадикальной в свой адрес и считает себя партией здравого смысла, новым языком апеллирующей к современным проблемам общества, о которых предпочитают не говорить другие политические силы. Тем не менее, многие избиратели видят в ней опасную реинкарнацию неофранкистской идеологии, несовместимую с демократическим устройством страны.

«Задумаемся, например, над предложением упразднить Конституционный суд, передав его функции одному из подразделений Верховного суда. Или предложение об изменении электоральной системы, - писала газета «El Pais». - Оба они потребуют, чтобы быть реализованными, конституционной реформы, ибо абсолютно противоречат различным статьям кон-

\footnotetext{
${ }^{1}$ La Razon, 18.02.2019.
} 
ституции 1978 г. Эти реформы - длинный путь, у которого может и не быть конца... Морочить голову избирателям нереализуемыми идеями со временем приведёт их к глубокому разочарованию в такой партии» ${ }^{1}$.

Соперничество трёх правых партий на одном избирательном поле принесло долгую головную боль ведущей из них и при нынешней системе выборов в сенат - верхнюю палату парламента, где социалисты также получили большинство, лишив НП возможности осуществить главное электоральное обещание в отстаивании целостности страны в противостоянии с Каталонией и в борьбе с «предателем» Санчесом. Только этот институт законодательной власти имеет право вводить в действие 155 статью «бессрочно и во всей ее полноте», как обещал избирателям лидер народников. Можно с уверенность утверждать, что социалисты вряд ли решатся вновь использовать её в противостоянии с каталонскими сепаратистами даже при худшем варианте развития событий, помня о печальном опыте в недавнем прошлом.

Означает ли эта предвыборная картина конец двухпартийной политической системы Испании, о чём много говорилось в последние годы после появления на сцене Подемос и Сьюдаданос, а теперь и Vox? Теоретически - да, хотя реальную борьбу за власть пока способны вести лишь инкорпорированные в общество народники и социалисты, все остальные у них на подхвате, как бы они ни старались представлять себя альтернативой обоим традиционным соперникам. Уже очевидно, что Подемос не выдержала испытания временем. Её электорат разочарован положением в партии, каудилизмом её лидера, идеологическим раздраем, из-за которого из пяти основателей в ней остался лишь один П. Иглесиас, и покидает её. Она потеряла почти треть депутатских мест и больше миллиона голосов избирателей, значительно ослабив своё представительство и влияние на принятие решений в парламенте, что практически лишает её шансов войти в состав социалистического правительства меньшинства ${ }^{2}$.

\section{Выводы}

Такой предвыборной неразберихи в постфранкистской Испании и такой борьбы за правого избирателя ещё не было. Вся пропагандистская машина правых всё это время из всех орудий била по социалистам и их виртуальным союзникам, но это им не помогло - социалисты победили с большим преимуществом при невероятно высокой для Испании явке избирателей (свыше 75\%). В то же время впервые за 40 лет постфранкистской истории Испании в парламент с 24 депутатскими мандатами вошли правые радикалы как эхо поправения европейского избирателя. Что всё это означает для политической системы страны, покажет время. Способность социалистов вернуться во власть после нескольких сокрушительных поражений на предыдущих выборах говорит о возрождении партии, её укоренённости в обществе и прагматизме новых лидеров. Правительство меньшинства может оказаться при нынешнем раскладе политических сил в стране не менее жизнеспособным, чем правительство большинства. Тем более что социалисты с большим преимуществом выиграли многие региональные выборы.

\section{Список литературы}

Филатов Г. Выборы в Испании: конец постфранкизма? 08.05.2019. URL: https://russiancouncil.ru/analytics-and-comments/analytics/vybory-v-ispanii-konets-postfrankizma/

Хенкин С. Испания: победа социалистов и метаморфозы в правом лагере. 30.04.2019. URL: https://russiancouncil.ru/analytics-and-comments/analytics/ispaniya-pobeda-sotsialistov-imetamorfozy-v-pravom-lagere/

\footnotetext{
${ }^{1}$ El Pais, 14.03.2019.

${ }^{2}$ Ibid, 06.05.2019.
} 


\section{References}

Filatov G. Vybory $\mathrm{v}$ Ispanii: konets postfrankizma? 08.05.2019. URL: https://russiancouncil.ru/analytics-and-comments/analytics/vybory-v-ispanii-konets-postfrankizma/

Khenkin S. Ispaniya: pobeda sotsialistov i metamorfozy v pravom lagere. 30.04.2019. URL: https://russiancouncil.ru/analytics-and-comments/analytics/ispaniya-pobeda-sotsialistov-imetamorfozy-v-pravom-lagere/

\section{Parliamentary Elections in Spain: The Socialists Came back into Power and Now for a Long Time}

Author. Vladimir Vernikov, Senior Research Associate, Head of Center for Iberic studies, Department of Countries Studies, Institute of Europe, Russian Academy of Sciences. Address: 113, Mokhovaya str., Moscow, Russia, 125009. E-mail: vverkai@ gmail.com.

Abstract. The author analyses the results of the parliamentary elections in Spain, the winner of which was the Spanish socialist workers party (PSOE), and the subsequent long period of search for allies to create a left-wing government. The 123 seats it won in the Congress of deputies - the lower house of Parliament - were not enough to win a vote in it alone (176 votes are needed) and to bring her leader Pedro Sánchez to power. The natural ally was the Podemos party (41 deputies), of which there is little left in the last year or two. But even with successful negotiations with its ambitious leader Pablo Iglesias, this would not be enough. P. Sanchez categorically rejected the very possibility of a bloc with the party of Sudadanos («Citizens»), which subjected him during the election campaign to vehement accusations of pre-giving national interests and pandering to the Catalan separatists. At the same time, he avoided the option of negotiations with the same left-wing Republicans of Catalonia, active supporters of the independence of the region, so as not to be bound by any promises for the future. Solitaire remained open to Basque nationalists and small regional Deputy groups, although in this case, not everything was clear. The result is known: the leader of the socialists was the crucible of Parliament. The author gives a forecast of the situation in Spain after the most unpredictable early parliamentary elections, which largely changed the political landscape of the country.

Keywords: snap elections, Vox Ultra-radicals, parliamentary vote, new political leaders, social-economic decrees, fight for the center-right, crisis in «Podemos», prospects of Left-wing parties.

DOI: http://dx.doi.org/10.15211/vestnikieran320193641 